\title{
Nuclear power uneconomic says congressional committee
}

THE House of Representative's committee on government affairs has published a damning indictment of claims that nuclear power is a cheap form of energy, claiming this only to be true if hidden costs such as federal subsidies and the costs of waste management are ignored.

The report, which was made public last week and is based on hearings held last autumn by the committee's subcommittee on the environment, energy and natural resources, states unequivocally: "Contrary to widespread belief, nuclear power is no longer a cheap energy source".

It continues: "In fact, when the still unknown costs of radioactive waste and spent nuclear fuel management, decommissioning and perpetual care are finally included in the rate base, nuclear power may prove to be much more expensive than conventional energy alternatives such as coal".

And the report adds that nuclear power may not either be economically competitive with safe, renewable resource energy alternatives such as solar power.

The report has already raised fierce controversy in Congress. Many members of the committee have recorded dissenting views, some claiming that although it purports to be concerned with the more efficient management of the nuclear power programme, its whole tenor is anti-nuclear. Others claim that it takes a superficial look at many complex scientific and technical issues.

However in the present political climate, the report provides a powerful political weapon in the hands of those who argue that the apparent economic unattractiveness of alternatives such as solar energy is a result of distortions due to federal subsidies of the nuclear programme.

Stating that both Congress and the
American people should be aware of the full implications of the nuclear option, the report points out that although there was initially a very rapid growth in the building of reactors up to the early 1970s, a variety of economic, technological and safety issues had since contributed to a sharp fall-off in orders.

Among the factors leading to increased estimates of the costs of nuclear power, the report lists the facts that:

- construction costs for a nuclear plant are increasing more rapidly than the general rate of inflation, or 10 times faster than those for an oil refinery

-nuclear plants are experiencing serious cost over-runs-as much as $267 \%$ for one plant

- the cost of uranium has risen from $\$ 7$ per pound in 1973 to more than $\$ 40$ per pound today for new sales

-various "hidden costs" and "extra costs", such as federal subsidies for nuclear power research and development, and limited liability and insurance are not incorporated in electric rates

- unknown costs, such as those associated with the "back end" of the fuel cycle, have not been determined, and are not incorporated in the price of electricity.

The report concentrates in particular on the difficulties of predicting the costs of storing radioactive waste, pointing out that Department of Energy estimates for disposing only military wastes had ranged from $\$ 2$ billion to $\$ 20$ billion. Similar uncertainty exists about the costs of decommissioning power plants.

The report recommends a number of actions which the Department of
Energy should undertake to gain the necessary technical and economic information about waste storage. And it concludes by suggesting that Congress should consider repealing the PriceAnderson Act and allow the nuclear industry to assume full liability and responsibility for the safe operation of commercial power plants.

Meanwhile support for the technical potentiality of moving into a nonnuclear future has come from another source, a study carried out jointly by the University of California and two of the Department of Energy's national laboratories, Lawrence Berkeley and Lawrence Livermore Laboratories.

Their preliminary report on the potential of energy systems using decentralised technologies to meet California's future energy needs was published at the end of last month. The report was prepared as part of the Department of Energy's response to the challenge laid down eighteen months ago by Amory Lovins on the possibility of moving from "hard" to "soft" energy paths.

Although the report does not look at the economic aspects of changing to different energy technologies, it concludes that soft technologies such as sun and hydro-power, wind, biomass and geothermal energy might be able to meet most of the state's needs by the year 2025 .

Making various assumptions about the future development of Californian society-such as an approximate doubling of population, tripling of total economic activity and quadrupling of energy prices in 2025-the report says that "analysis indicates that it is possible in purely technical terms, to come quite close to operating the postulated advanced, post-industrial society in California using indigenous, sustainable resources".

David Dickson

\section{Sakharov speaks in support of nuclear power}

"Development of nuclear energy is an indispensible condition for the maintenance of economic and political independence," according to Academician Andrei D. Sakharov.

Writing in the Neue Zïrcher Zeitung, Sakharov expresses his alarm at the "numerous noisy demonstrations" in the West against the building of nuclear power stations. For western Europe and Japan, with their dwindling supplies of fossil fuels, the alternative to nuclear power is "dangerous" economic dependence on "energy supplies in the form of fossil fuels from the USSR or from countries under its influence which produce oil and natural gas".

By threatening to withhold energy supplies, he says, the Soviet Union could win for itself political concessions, each leading "inevitably" to the next, with a final outcome that is "very difficult to predict".

Explaining Soviet policy, Sakharov recalls a conversation which he had in 1955 with "a high Soviet official" who implied that Soviet policy in the Middle East was supporting Nasser so as to cause an oil shortage in western Europe. Today, he says, "the situation is very complicated and has many facets", but the parallel remains. The Soviet Union still has an interest in "profiting from the energy weakness of the West".

Regarding possible Soviet inspiration behind the campaigns, Sakharov is noncommittal. "We know of no facts about this," he says. Nevertheless, in his opinion, "the widespread prejudice against nuclear energy and the lack of insight concerning the inevitability of the atomic age" mean that, if there should be some Soviet influence involved, only a very slight effort would be needed.

Vera Rich 